\title{
What exactly did the judge decide? Clear language and well-arranged structure lead to better comprehensible court judgments
}

\author{
Marieke Geerlings, MSc \\ Public administration specialist, \\ Faculty of Social Sciences, VU University Amsterdam \\ De Boelelaan 1081, $1081 \mathrm{HV}$, the Netherlands \\ André van Montfort, PhD \\ Associate professor, \\ Faculty of Social Sciences, VU University Amsterdam \\ De Boelelaan 1081, $1081 \mathrm{HV}$, the Netherlands
}

\begin{abstract}
In recent years, judicial authorities in the Netherlands have started paying more and more attention to the linguistic and textual quality of their judgments. This is based on the assumption that a better linguistic and textual quality of court judgments leads to the content of these judgments being better understood by citizens and private or public organizations. However, to what extent is this plausible assumption empirically correct? To answer this question, an original administrative law judgment from a Dutch district court was rewritten on the basis of a number of linguistic and textual quality requirements from the literature. Subsequently, a digital survey was conducted among 106 respondents. Half of the respondents answered a number of substantive questions about the original version of the court judgment. The other half of the respondents answered the same substantive questions about the rewritten version. According to the answers to the substantive questions, the second group of respondents understood the content of the court judgment considerably better than those to whom the original version of the court judgment was presented. The higher linguistic and textual quality of the rewritten version ensured that the content of the court judgment was better understood.
\end{abstract}

Keywords: Linguistic quality, textual quality, comprehensibility court judgment, administrative law, district court

\section{INTRODUCTION}

In recent years, there has been increasing emphasis within the Dutch judiciary on the comprehensibility of court judgments. Court judgments should be clearly formulated and thereby understandable to citizens, firms and government bodies (Meijer, 2018; Van der Bruggen, 2018). Understandable court judgments reduce the risk that the judgment will not be accepted or misinterpreted by those to whom it concerns (Reinsma \& Reinsma, 1976; Nolta, 1997). Court judgments are not only intended for lawyers, they are also written for the people and organizations directly involved and the whole society (Nolta, 1997). Everyone and every private or public organization can be confronted with a court judgement, which might have farreaching consequences. Courts and their judgments must therefore be verifiable for all persons and organizations directly involved and the entire society (Verkuylen, 2002). The use of clear language can help considerably in that regard (De Poot, Verkuylen, \& Malsch, 2007). Well written court judgements are easier to understand (Meijer, 2018; Van der Bruggen, 2018). 
Not everyone shares the opinion that court judgments should be written as simply as possible. The essence of legal arguments and their adequacy could then easily be lost (Merckelbach, 2018). However, this is a minority view. Most lawyers and experts believe that there are good opportunities to improve the linguistic and textual quality of court judgments without affecting their legal quality (Van der Bruggen, 2018).

A number of Dutch courts have started initiatives to increase the readability and comprehensibility of court decisions. This led to the national project What I Actually Mean (in Dutch: Wat Ik Eigenlijk Bedoel - WIEB). As part of that project, judges and secretaries from the administrative law sector of the Amsterdam District Court received feedback from a linguist to develop the clearest possible writing style. The style of writing must be such that judgments from the administrative law sector are also understandable for non-lawyers.

In addition to the judiciary, researchers have also been paying increasing attention in recent years to the readability and comprehensibility of judgments and other legal documents. Jansen and Steehouder (1989) and Van der Pool and Van Wijk (2010) have already done research in this area. In both investigations, forms and letters from district courts were rewritten. Both the original documents and the rewritten versions were presented to a group of respondents. Both investigations concluded that the rewritten legal documents were assessed to be better by respondents (Jansen \& Steehouder, 1989; Van der Pool \& Van Wijk, 2010).

The foregoing does not alter the fact that research into the readability and comprehensibility of legal texts is relatively scarce. Against this background, in mid-2019 we executed a research project on the linguistic and textual quality of Dutch court judgments and their comprehensibility for non-lawyers (Geerlings, 2019). The research project focused on court judgments in the field of administrative law. Administrative law contains standards that government bodies must adhere to when they make decisions with regard to citizens, businesses and other government organizations. This concerns, for example, standards that apply to the granting of subsidies, the levying of all kinds of taxes, the granting of building permits, and the providing of environmental permits. The present research project was based on the following central question: What is the relationship between the linguistic and textual quality of an administrative law court judgment and its comprehensibility for citizens?

\section{THEORETICAL FRAMEWORK}

The theoretical framework from which the research was conducted consists of three parts, namely a number of linguistic and textual quality requirements for administrative law judgments, a definition of the concept of 'comprehensibility' (of administrative law judgments), and a hypothesis about the relationship between, on the one hand, the linguistic and textual quality of an administrative law judgment and, on the other hand, the comprehensiveness of this judgment for citizens. The three parts of the theoretical framework are further explained below.

\section{Linguistic and textual quality requirements for an administrative law judgment}

A number of linguistic and textual quality requirements for an administrative law judgment can be distilled from the literature. The quality requirements most frequently mentioned in the literature are shown later in this article in the left-hand column of Figure 1 . These requirements can help to increase the comprehensibility of the court judgment for citizens (Flesch, 1977; Nolta, 1997; Gerits, 1999; Mellinkoff, 2004, Van der Bruggen, 2018). Two quality requirements are now explained by way of illustration. 
An example of a linguistic quality requirement is that the use of formal and old-fashioned words must be avoided. Consider, for example, words such as "de onderhavige" (meaning "the present"), "mitsdien" (meaning 'therefore") and "desalniettemin" (meaning "nonetheless"). Such words are unusual in the general language, but appear to be common in court judgments (Gertis, 1999). They to some extent create a gap between the court that produced the judgment and the citizen who reads it (Malsch, De Poot, Verkuylen, \& Wolters, 2004).

An example of a textual quality requirement is that the court judgment must make clear as quickly as possible what the court has decided on the essence of the legal dispute. When reading the judgment, lawyers immediately look for the decision that the court has taken with regard to the essence of the legal dispute. This decision is usually displayed at the end of the judgment. After lawyers have read the conclusion at the end of the text, they then go through the judgment from the back to the front. Given the foregoing it makes more sense to put the judge's conclusion at the front of the text. Yet placing the conclusion at the front of the text feels strange to a judge. Traditionally, he reasons in the direction of a particular conclusion presented at the end of the judgment. Nevertheless, it is possible to start the text with the conclusion. The court judgement is then easier to follow for a citizen (Van der Bruggen, 2018).

\section{Comprehensibility of an administrative law judgment}

With regard to the comprehensibility of an administrative law court judgment, a distinction can be made between the judgments perceived comprehensibility and its actual comprehensibility. The self-perceived comprehensibility of a court judgment concerns the extent to which citizens themselves think they understand the content of the judgment in question (regardless whether their perceptions are correct or wrong). The actual comprehensibility of a court judgement refers to the extent to which citizens according to objective criteria actually understand the content of the judgment.

Two aspects can be distinguished from the actual comprehensibility of an administrative law judgment. These aspects are shown below in the right-hand column of Figure 1. The one aspect is that from the text of the judgment, citizens must be able to determinate what the court has actually decided on the legal dispute that has been submitted to the court. In other words, to what extent is it clear to citizens whether the court judgment for the person or organization that has appealed to the court against a decision of a particular governmental body yields what that person or organization wanted to achieve by appealing? And to what extent is it clear to citizens what specific consequences the court judgment has for the rights and obligations of the person or organization that has appealed, for the rights and obligations of any other parties involved, and for the rights and obligations of the government body that made the decision that has been judged by the court (Geerlings, 2019)? The other aspect is that from the text of the judgment, citizens must be able to see what arguments the judge has had for his decision about the dispute that has been submitted to him. To what extent is it clear to citizens what reasoning, argument or substantiation the court gives for its judgment (Geerlings, 2019)? All in all, a judgment is therefore more actually comprehensible in proportion as citizens are better able to state what the court decided exactly in its judgment and why the court did so.

We assume that both the self-perceived comprehensibility and the actual comprehensibility of a judgment depend, among other things, on the linguistic and textual quality of the judgment.

\section{Relationship between linguistic and textual quality of a judgment and its comprehensibility}

It is suggested in the literature that a higher linguistic quality of a court judgment is accompanied by a greater comprehensibility of the individual sentences for citizens. However, 
a higher linguistic quality does not ensure that the entire text of the judgment also gains in comprehensibility for citizens (De Poot, Verkuylen, \& Malsch, 2007). Textual quality requirements must also be met for a better understanding of the entire judgment. If attention is paid to both linguistic quality requirements and textual quality requirements in a court decision, it is not only expected that the understanding of individual sentences will improve among citizens, but the understanding of the judgment as a whole will probably also increase (Sanders \& Jansen, 2011; Van der Bruggen, 2018).

The above leads to the following hypothesis: The higher the linguistic and textual quality of a court judgment, the more comprehensible the judgment will be for citizens. The term "comprehensibility" in this hypothesis refers to both the self-perceived and the actual comprehensibility of the judgment. In Figure 1, the hypothesis is symbolized by means of an arrow.

Linguistic quality requirements:

1. No words with double meaning

2. Informal and contemporary words

3. No foreign words such as Latin phrases

4. No over-precision

5. Direct speech

6. Maximum of 35 words per sentence

7. No short sub-sentences

8. No tang constructions

9. No noun style

10. Active sentences

11. No double denials

12. No preposition accumulations

Textual quality requirements:

13. Explanation of procedures

14. Description of judgment's legal consequences

15. Entire text is at the service of clarifying judgment's most important message

16. Introduction explicates central question that will be answered

17. Central question is answered as quickly as possible

18. Judgment can be scanned quickly and well due to structuring elements such as informative headers and short paragraphs

Self-perceived comprehensibility

Actual comprehensibility:

1. Citizens can state which decision or decisions the court has taken

2. Citizens can state why the court has taken this decision or these decisions

Figure 1: Linguistic and textual quality requirements in relation to comprehensibility of court judgment (Source: Geerlings, 2019) 


\section{DATA COLLECTION AND ANALYSES}

The empirical study was conducted on the basis of an administrative law judgment of a Dutch court. The judgement was made by one single administrative judge, assisted by a clerk.

\section{Selected Court Judgment}

We have selected the court judgment from a large group of recent administrative law judgments that have been published on www.rechtspraak.nl. The selected court judgment concerns an appeal lodged by an unemployed citizen who had applied to the Uitvoeringsinstituut Werknemersverzekeringen (UWV), a national government agency in the field of social security, for a so-called "training voucher". The voucher would offer him as a jobseeker a financial allowance if he were to follow a course to increase his chances on the labor market. The UWV rejected the application for the training voucher. The citizen did not agree with this and appealed to the court.

The judgment of the administrative court contains various elements. Firstly, the court upheld the appeal and annulled the UWV's decision to reject the application for a training voucher. The court put forward as an argument that the UWV had made a procedural error at an earlier stage. The UWW had in fact failed to give the citizen the opportunity to be heard about his objections to the rejection of the application for a training voucher. Secondly, the court ruled that the rights and obligations arising from the rejection decision for the citizen and the UWV remain intact despite the annulment of this decision. As a result, the citizen in question is still not entitled to a training voucher. The UWV still does not have to grant him a voucher despite the annulment of the rejection decision. The judge gave as argument for this that the citizen could no longer claim the voucher when he made the application for the training voucher. Thirdly, the judge ruled that the UWV should provide the citizen with financial compensation for the costs that the citizen had to incur for filing the appeal with the court. The judge motivated this element of his judgment with the argument that the appeal was upheld. Finally, in the selected judgment, the court ruled that the UWV did not have to provide the citizen with financial compensation for the costs that the citizen had to incur when he challenged the rejection decision at an earlier stage with the UWV.

The court judgment has been selected on the basis of four criteria. The judgment should be: 1) recent (that is, published in 2018 or 2019), 2) not too long (that is, at the most 5 pages), 3) not too difficult in substantive and legal respect, and 4) not too easy (that is, offering sufficient possibilities for linguistic and textual improvement).

We have rewritten the selected court judgment based on the quality requirements listed in the left-hand column of Figure 1. The rewritten version of the court judgment was subsequently commented on at our request by two administrative law judges and one administrative law court clerk. These three functionaries work at a different court than the court from which the original judgment came. Their comments have ensured that the content of the original version of the court judgment and the content of its rewritten version are identical.

\section{Determining the linguistic and textual quality of both versions of the judgment}

The linguistic and textual quality of the judgment has been determined for both the original version and the rewritten version of the judgment. This was done on the basis of the eighteen linguistic and textual quality requirements that are shown in the left-hand column of Figure 1.

A score of 0,1 or 2 points could be achieved per quality requirement. A score of 0 points was awarded if the (original or rewritten version of the) judgment did not meet the linguistic or 
textual quality requirement in question. A score of 1 point was given if the judgment met the quality requirement to some extent and a score of 2 points was granted if the judgment met the requirement to a high degree. Given the eighteen quality requirements, in this way a minimum of $0(=18 \times 0)$ points and a maximum of $36(=18 \times 2)$ points could be awarded in total. A total score of 36 points indicates a very high linguistic and textual quality of the judgment. A total score of 0 points, on the other hand, refers to a very low quality.

The total score for the (original or rewritten version of the) judgment has then been standardized by dividing the total score by eighteen, being the total number of quality requirements on which the total score is based. This division of the total score by eighteen resulted in a standardized score between 0 and 2 . Whereas a score of 0 indicates a very poor linguistic and textual quality, a score of 2 refers to a very good linguistic and textual quality.

\section{Determining the comprehensibility of both versions of the judgment by means of a survey}

To determine the extent to which the original and the rewritten version of the judgment are comprehensible to citizens, a digital survey was conducted among friends and acquaintances of the first author of this article. The survey was conducted from the end of May to mid-June 2019. The questions had to be answered via the Qualtrics program. A total of 106 respondents participated in the survey. Half of the respondents answered a number of substantive questions about the original version of the judgment. The other half answered the same questions about the rewritten version of the judgment.

Every respondent first had to read the (original or rewritten version of the) judgment and then complete a short questionnaire. The first part of the questionnaire focused on a few personal characteristics of the respondent, such as his or her age and gender. These characteristics were used as control variables in the study (see also section 3.4).

The following four questions were aimed at determining the actual comprehensibility of the judgment for citizens. The questions were intended to find out whether the respondent was able to state (a) which decisions the judge took and (b) why the judge made these decisions. Specifically, the following questions were asked:

1) Should the UWV - according to the court's decision - grant the claimant a training voucher?;

2) Should the UWV - according to the court's decision - give compensation to the claimant for the costs incurred by the claimant in connection with filing a notice of objection with the UWV?;

3) Should the UWV - according to the decision of the court - give compensation to the claimant for the costs incurred by the claimant in connection with filing an appeal with the court?; and

4) Why does the court uphold the claimant's appeal?

These four questions to establish the actual comprehensibility of the judgment for citizens were closed in character. In other words, it concerned multiple choice questions. For all four questions, the respondents had the choice of four answer options, with "I don't know" always being the last answer option. For each question, the correct answer earned 2 points. An incorrect answer yielded 0 points and the answer "I don't know" resulted in 1 point. The respondent was therefore able to meet a minimum of $0(=4 \times 0)$ and a maximum of $8(=4 \times 2)$ points for questions about the actual comprehensibility of the judgment. This total score has also been standardized. This was done by dividing the score by 4 , so that the actual 
comprehensibility of the judgment was ultimately expressed for each respondent in a number between 0 and 2 .

The questionnaire ended with one question to determine the self-perceived comprehensibility of the judgment for citizens. This question was:

"What rating would you give for the comprehensibility of this court judgment?

(The rating 0 means that it is completely unclear to you what this judgment is about. The rating 10 means that the content of the judgement is completely clear to you).

\section{Control Variables}

At the very beginning of the survey, three questions were asked about the following personal characteristics of the respondent: gender, age and level of education. The respondent was also asked a question about the extent to which he or she has (had) to deal with legal subjects or legal issues in his or her job or study. All these four background questions had a closed character, with the respondent always having to choose from a number of answer categories. The background questions were used as control variables in the statistical analyses of the assumed relationship between the linguistic and textual quality of the court judgment and its comprehensibility for citizens.

\section{Statistical Analyses}

The survey data was analyzed using the SPSS computer program. A number of One-sample T tests were first carried out to determine to what extent the sample of 106 respondents was representative of the total Dutch population. Subsequently, frequency distributions were made that reflect the extent to which the respondents understood the (original or rewritten version of the) judgment. Finally, linear regression analyses were used to test the hypothesis formulated in section 2.3 (about the relationship between quality and comprehensibility).

In the linear regression analyses, with respect to the "gender" control variable, the "can or want not say" response category was interpreted as a missing value. Furthermore, the "age", "education level" and "legal experience" control variables have been dichotomized because these variables were at an ordinal or interval level. With regard to age, a distinction has been made between young respondents (up to and including 39 years old) and old respondents (from 40 years old). For educational level, higher professional education and academic education were considered to be high level and all other forms of educations were perceived as low level. Concerning legal experience, a distinction has been made between respondents without any legal experience and respondents who have such experience to a limited, moderate or large extent. For the linear regression analyzes, a confidence interval of 5 percent $(\mathrm{p}<0.05)$ was used.

\section{RESULTS}

Before presenting the survey data and analyzing them statistically, a picture of the linguistic and textual quality of the judgement is first given for each of the two versions of the judgment submitted to the respondents.

\section{Comparison between both versions of the judgment in terms of linguistic and textual quality}

Table 1 shows that the linguistic and textual quality of the rewritten version of the judgment is considerably higher than that of the original version. This applies to the linguistic quality separately, to the textual quality separately and to the linguistic and textual quality together. 
Table 1: Linguistic and textual quality for both versions of judgment

\begin{tabular}{|c|c|c|}
\hline Scores per linguistic quality requirement & Original version & Rewritten version \\
\hline 1. No words with double meaning & 2 & 2 \\
\hline 2. Informal and contemporary words & 0 & 2 \\
\hline 3. No foreign words such as Latin phrases & 1 & 2 \\
\hline 4. No over-precision & 2 & 2 \\
\hline 5. $\quad$ Direct speech & 0 & 2 \\
\hline 6. Maximum of 35 words per sentence & 0 & 1 \\
\hline 7. No short sub-sentences & 1 & 2 \\
\hline 8. No tang constructions & 1 & 2 \\
\hline 9. No noun style & 0 & 1 \\
\hline 10. Active sentences & 2 & 2 \\
\hline 11. No double denials & 1 & 2 \\
\hline 12. No preposition accumulations & 2 & 2 \\
\hline Total score linguistic quality & $12 \rightarrow 0,5(=12 / 24)$ & $22->0,92(=22 / 24)$ \\
\hline Scores per textual quality requirement & Original version & Rewritten version \\
\hline 13. Explanation of procedures & 0 & 2 \\
\hline $\begin{array}{l}\text { 14. Description of judgment's legal } \\
\text { consequences }\end{array}$ & 1 & 2 \\
\hline $\begin{array}{l}\text { 15. Entire text is at the service of clarifying } \\
\text { judgment's most important message }\end{array}$ & 0 & 1 \\
\hline $\begin{array}{l}\text { 16. Introduction explicates central question } \\
\text { that will be answered }\end{array}$ & 1 & 2 \\
\hline $\begin{array}{l}\text { 17. Central question is answered as quickly as } \\
\text { possible }\end{array}$ & 0 & 1 \\
\hline $\begin{array}{l}\text { 18. Judgment can be scanned quickly and well } \\
\text { due to structuring elements such as } \\
\text { informative headers and short paragraphs }\end{array}$ & 0 & 2 \\
\hline Total score textual quality & $2->0,17(=2 / 12)$ & $10->0,83(=10 / 12)$ \\
\hline Total score linguistic and textual quality & $14->0,39(=14 / 36)$ & $32->0,89(=32 / 36)$ \\
\hline
\end{tabular}

The two versions of the judgment were submitted to a sample of 106 respondents. How was the sample composed and to what extent was it representative of the total Dutch population?

\section{Composition and Representativeness of the Sample}

It can be seen from Table 2 that more women than men participated in the survey. Furthermore, more than half of the respondents were between 20 and 40 years old and more than half of them had a bachelor's or master's degree. Finally, almost all respondents had only limited or no experience with legal subjects in their education or work situation. The legal knowledge of the respondents is therefore rather limited. 
Geerlings, M., \& Montfort, A. V. (2020). What exactly did the judge decide? Clear language and well-arranged structure lead to better comprehensible court judgments. Archives of Business Research, 8(1), 248-260.

Table 2: Personal characteristics of respondents for both versions of judgment

\begin{tabular}{|c|c|c|c|}
\hline Gender & Original version & Rewritten version & Total \\
\hline Male & $52,8 \% \quad(28)$ & $66,0 \% \quad(35)$ & $59,4 \% \quad(63)$ \\
\hline Female & $45,3 \% \quad(24)$ & $34,0 \% \quad(18)$ & $39,6 \% \quad(42)$ \\
\hline Can or want not say & $1,9 \% \quad(1)$ & $0,0 \% \quad(0)$ & $0,9 \% \quad(1)$ \\
\hline Total & $100,0 \%$ (53) & $100,0 \%(53)$ & $\begin{array}{l}99,9 \% \\
(106)\end{array}$ \\
\hline Age category & Original version & Rewritten version & Total \\
\hline $10-19$ years & $7,5 \% \quad(4)$ & $1,9 \% \quad(1)$ & $4,7 \%$ \\
\hline $20-29$ years & $32,1 \% \quad(17)$ & $47,2 \% \quad(25)$ & $39,6 \% \quad(42)$ \\
\hline $30-39$ years & $15,1 \% \quad$ (8) & $13,2 \%$ & $14,2 \%$ \\
\hline $40-49$ years & $13,2 \% \quad(7)$ & $7,5 \% \quad(4)$ & $10,4 \%$ \\
\hline $50-59$ years & $15,1 \% \quad(8)$ & $22,6 \% \quad(12)$ & $18,9 \% \quad(20)$ \\
\hline $60-69$ years & $15,1 \% \quad(8)$ & $5,7 \%$ & $10,4 \%$ \\
\hline$\geq 70$ years & $1,9 \% \quad(1)$ & $1,9 \%$ & $1,9 \% \quad(2)$ \\
\hline Total & $100,0 \%$ (53) & $100,0 \%$ & $\begin{array}{l}100,1 \% \\
(106)\end{array}$ \\
\hline Educational level & Original version & Rewritten version & Total \\
\hline Primary school & $0,0 \% \quad(0)$ & $0,0 \% \quad(0)$ & $0,0 \% \quad(0)$ \\
\hline $\begin{array}{l}\text { Pre-vocational secondary education } \\
\text { ("VMBO") or Secondary vocational } \\
\text { education ("MBO"), level 1-3 }\end{array}$ & $11,3 \% \quad(6)$ & $7,5 \% \quad(4)$ & $9,4 \% \quad(10)$ \\
\hline $\begin{array}{l}\text { Secondary vocational education ("MBO"), } \\
\text { level } 4 \text {, or Senior general secondary } \\
\text { education ("HAVO") }\end{array}$ & $18,9 \% \quad(10)$ & $18,9 \%(10)$ & $18,9 \% \quad(20)$ \\
\hline Pre-university education ("VWO") & $3,8 \% \quad(2)$ & $1,9 \% \quad(1)$ & $2,8 \% \quad(3)$ \\
\hline $\begin{array}{l}\text { Higher professional education ("HBO"), } \\
\text { bachelor degree, or University education } \\
\text { ("WO"), bachelor degree }\end{array}$ & $37,7 \quad(20)$ & $32,1 \%(17)$ & $34,9 \% \quad(37)$ \\
\hline $\begin{array}{l}\text { University education (“WO”), master } \\
\text { degree }\end{array}$ & $28,3 \% \quad(15)$ & $39,6 \% \quad(21)$ & $34,0 \% \quad(36)$ \\
\hline Total & $100,0 \%(53)$ & $100,0 \%(53)$ & $\begin{array}{l}100,0 \% \\
(106)\end{array}$ \\
\hline Legal experience & Original version & Rewritten version & Total \\
\hline Much & $0,0 \% \quad(0)$ & $3,8 \% \quad(2)$ & $1,9 \%$ \\
\hline Moderate & $1,9 \% \quad(1)$ & $0,0 \% \quad(0)$ & $0,9 \% \quad(1)$ \\
\hline Little & $26,4 \% \quad(14)$ & $15,1 \% \quad(8)$ & $20,8 \%(22)$ \\
\hline None & $71,7 \% \quad(38)$ & $81,1 \% \quad(43)$ & $76,4 \% \quad(81)$ \\
\hline Total & $100,0 \%(53)$ & $100,0 \%(53)$ & $100,0 \%(106)$ \\
\hline
\end{tabular}

According to StatLine, the database of Statistics Netherlands, the Dutch population in 2018 consisted for about 50 percent of females, for about 25 percent of people aged 20 to 39, and for about 30 percent of young people and adults studying or graduated in higher professional education or university education. The results of the One Sample T tests show that the research sample is not representative of the Dutch population in terms of gender $(\mathrm{p}=$ $0,04)$, age $(p=0,00)$ and education level $(p=0,00)$. Females, people in the 20 to 39 age group, and highly educated people were overrepresented. Due to a lack of information about the legal experience within the total population of Dutch people, we were unable to check whether the sample is representative on this point. 


\section{Comprehensibility of the Court Judgment for Respondents}

How understandable are the original version and the rewritten version of the judgment for the respondents? In answering this question, we make a distinction between the extent to which respondents think they have understood the statement (self-perceived comprehensibility) and the extent to which they have actually understood this statement (actual comprehensibility).

As far as the self-perceived comprehensibility of the judgment is concerned, the respondents found the content of the original version difficult to understand. The respondents gave an average a score of 4.27 (on a scale of 0 to 10) for the comprehensibility of the original version. However, the respondents found the content of the rewritten version of the judgment considerably better understandable. They rated the comprehensibility of this version on average with a score of 7.09. Table 3 contains more detailed information.

Table 3: Self-perceived comprehensibility for both versions of judgment

\begin{tabular}{ll|ll|ll}
\hline Rating given by respondent & \multicolumn{3}{|l|}{ Original version } & \multicolumn{2}{l}{ Rewritten version } \\
\hline 0 & -1 & $7,8 \%$ & $(4)$ & $0,0 \%$ & $(0)$ \\
2 & -3 & $23,5 \%$ & $(12)$ & $1,9 \%$ & $(1)$ \\
4 & -5 & $45,1 \%$ & $(23)$ & $13,2 \%$ & $(7)$ \\
6 & -7 & $17,7 \%$ & $(9)$ & $50,9 \%$ & $(27)$ \\
8 & -9 & $5,9 \%$ & $(3)$ & $28,3 \%$ & $(15)$ \\
10 & $0,0 \%$ & $(0)$ & $5,7 \%$ & $(3)$ \\
\hline Total & $100,0 \%$ & $(51)$ & $100,0 \%$ & $(53)$ \\
\hline
\end{tabular}

(Missing cases original version $=2$; Missing cases rewritten version $=0$; Mean original version $=4.27$; Mean rewritten version $=7.09$ )

The question above was to what extent the respondents thought they understood the content of the judgment. However, it is more important to what extent the respondents actually understood this content. Table 4 shows that the respondents who answered the relevant survey questions for the original version of the judgment scored an average of 0.99 points (on a scale of 0 to 2). Expressed in a number on a scale from 0 to 10, this score corresponds with a 5. The respondents who answered the survey questions for the rewritten version of the judgment scored on average considerably higher, namely 1.40 points. That corresponds to a 7 on a scale from 0 to 10 .

Table 4: Actual comprehensibility for both versions of judgment

\begin{tabular}{lll|ll|ll}
\hline $\begin{array}{l}\text { Score calculated based on the number of } \\
\text { correct answers to survey questions }\end{array}$ & \multicolumn{3}{|l|}{ Original version } & \multicolumn{2}{|l}{ Rewritten version } \\
\hline 0 & - & 0,5 & $26,9 \%$ & $(14)$ & $5,7 \%$ & $(3)$ \\
$>0,5-$ & 1 & $36,5 \%$ & $(19)$ & $26,4 \%$ & $(14)$ \\
$>1$ & - & 1,5 & $30,8 \%$ & $(16)$ & $37,7 \%$ & $(20)$ \\
$>1,5-$ & 2 & 5,8 & $(3)$ & $30,2 \%$ & $(16)$ \\
\hline Total & $100,0 \%$ & $(52)$ & $100,0 \%$ & $(53)$ \\
\hline
\end{tabular}

(Missing cases original version $=1$; Missing cases rewritten version $=0$; Mean original version $=0.99 ;$ Mean rewritten version $=1.4$ )

\section{Testing of hypothesis about relationship of linguistic and textual quality with comprehensibility}

So, the rewritten version of the judgment is considerably better understood by the respondents than the original version. This not only applies to the self-perceived comprehensibility, but also to the actual comprehensibility. This fact supports our hypothesis that a judgment is more comprehensible to citizens if its linguistic and textual quality is higher. However, to test this hypothesis in a methodologically responsible manner, a number of 
control variables must be taken into account. We did this by including the control variables "gender", "age", "level of education" and "legal experience" in the linear regression analyses.

Table 5 shows that the self-perceived comprehensibility of the judgment depends on the version of the statement $(B=2.804, p=0.000)$. The same applies to the actual comprehensibility of the judgment $(B=0.428 p=0.000)$. Since the rewritten version of the pronunciation has a better linguistic and textual quality than the original version (Section 4.1), the results of the linear regression analyses confirm our hypothesis.

Table 5: Results linear regression analyses for self-perceived comprehensibility and actual comprehensibility of judgment

\begin{tabular}{|l|c|c|c|c|}
\hline \multirow{2}{*}{$\begin{array}{l}\text { Independent variable (i.e., original versus } \\
\text { rewritten version of judgment) and control } \\
\text { variables (e.g.gender and age) }\end{array}$} & \multicolumn{2}{|c|}{$\begin{array}{c}\text { Self-perceived } \\
\text { comprehensibility }\end{array}$} & \multicolumn{2}{|c|}{$\begin{array}{c}\text { Actual } \\
\text { comprehensibility }\end{array}$} \\
\cline { 2 - 5 } & $\mathrm{B}^{*}$ & $\mathrm{p}$ & $\mathrm{B}$ & $\mathrm{p}$ \\
\hline Original versus rewritten version of judgment & 2,804 & $\mathbf{0 , 0 0 0}$ & 0,428 & $\mathbf{0 0 0}$ \\
\hline Gender (male versus female) & 0,199 & 0,578 & $-0,260$ & $\mathbf{0 , 0 0 8}$ \\
\hline Age (whether or not younger than 40 years) & 0,311 & 0,417 & 0,031 & 0,767 \\
\hline $\begin{array}{l}\text { Educational level (whether or not level of } \\
\text { higher professional education or university } \\
\text { education) }\end{array}$ & 0,321 & 0,440 & 0,079 & 0,476 \\
\hline Legal experience (yes versus no) & & & & \\
\hline Constant & 0,569 & 0,174 & 0,288 & $\mathbf{0 , 0 1 1}$ \\
\hline
\end{tabular}

(* Unstandardized regression coefficient; p-values in bold indicate statistical significance $(p<0,05)$; Missing cases analyses self-perceived comprehensibility $=4$; Missing cases analyses actual comprehensibility $=3$ )

What is also striking in table 5 is that female respondents understood the (original or rewritten version of the) judgment better than male respondents. The actual comprehensibility of the judgment is greater for female respondents $(B=-0.260, p=0.008$ ). Furthermore, is also striking that respondents with legal experience understood the judgment better than respondents without such experience $(B=0.288, p=0.011)$.

\section{CONCLUSION AND DISCUSSION}

Scientists and lawyers assume that judgments that are more clearly written and structured will also be better understood by citizens and private or public organizations. However, this assumption is hardly based on empirical research. The present study therefore met a need. The research findings showed a positive relationship between the linguistic and textual quality of a court judgment and its comprehensibility. Clear formulations and a well-arranged structure led to a better comprehensible judgment. This applies both to the extent to which respondents thought they understood the judgment and to the extent to which they actually understood the judgment.

The greater comprehensibility of a judgment resulting from its clearer formulation and more proper structuring is in the first place useful for the parties directly involved in the dispute on which the court has decided. These parties then know better what rights and obligations they possess on the basis of the judgment and why the judge has created those rights and obligations. In the second place, greater comprehensibility of court judgments also promotes society's confidence in the judiciary. Society expects court judgments having a comprehensible content. 
However, the clear formulation and proper structuring of judicial judgments will not result in a full understanding of the judgment by everyone. In the present study, the rewritten version of the judgment was well understood by approximately 70 percent of the respondents. Despite the generally high level of education of the respondents, a substantial part of the respondents still did not have a good picture of the content of the judgment. So, no miracles are to be expected from a greater focus of courts on the linguistic and textual quality of judgments.

Much additional research is needed in this area. With regard to administrative law judgments, future research could also focus on substantive and/or legally more complex judgments than the one from the present study. The present study was about a judgment that pertained to a relatively simple case and was done by only one judge. Future research could also focus on more complex judgments made by a team of multiple judges. In the field of administrative law, joint decisions on complex cases are taken by a team of three judges.

Finally, future research could also focus on areas of law other than administrative law. To what extent is the clear formulation and well-arranged structuring of judgments also beneficial in areas other than administrative law, such as commercial law, corporate law and family law?

\section{BIBLIOGRAPHY}

De Poot, C.J., Verkuylen, M.W., \& Malsch, M. (2007). Leesbaarheid maakt gebrek aan kennis zichtbaar. Over de begrijpelijkheid van schriftelijke vonnissen [Readability makes lack of knowledge visible: About the comprehensibility of written judgments]. In: M. Malsch \& N. van Manen (Eds.), De begrijpelijkheid van de rechtspraak [The comprehensibility of the case law] (pp. 49-61). The Hague: Boom Juridisch.

Flesch, R. (1977). Helder schrijven, spreken, denken. Stap voor stap naar betere communicatie [Clear writing, speaking, thinking: Step by step to better communication]. Deventer: Van Loghum Slaterus.

Geerlings, M. (2019). Herschrijven loont. Een empirisch onderzoek naar de begrijpelijkheid van rechterlijke uitspraken [Rewriting pays off: An empirical study into the comprehensibility of court judgments] (Master's thesis). Amsterdam: Vrije Universiteit.

Gerits, J. (1999). Betere taal: meer recht. Handboek rechtstaalbeheersing [Better language, more law: Legal language improvement handbook]. Leuven: Acco.

Jansen, C., \& Steehouder, M. F. (1989). Overheidsformulieren aangepakt. Resultaten van een onderzoek naar verbeteringsmogelijkheden [Government forms addressed: Results of a study into possibilities for improvement]. Communicatief, 2(3), 152-162.

Meijer, R. (2018). Geen 'voorts' maar 'verder'. Coalitie wil eenvoudiger taal in vonnissen rechters [No "voorts" but "verder": Government wants simpler language in judgments]. De Volkskrant. Accessed on January 3, 2020 via https://www.volkskrant.nl/nieuws-achtergrond/geen-voorts-maar-verder-coalitie-wil-eenvoudiger-taal-invonnissen-rechters $\sim \mathrm{bdc} 987 \mathrm{ba} /$

Mellinkoff, D. (2004). The Language of the Law. Eugene, United States: Wipf and Stock Publishers.

Merckelbach, H. (2018, 13 augustus). Filmpjes en Klare Taal. Een gevaarlijk duo [Movies and Clear Language. A dangerous duo]. NRC. Accessed on January 3, 2020 via https://www.nrc.nl/nieuws/2018/08/31/filmpjes-enklare-taal-een-gevaarlijk-duo-a1614845

Nolta, J. V. (1997). Taal in toga. Over toegankelijke (straf)rechtstaal [Language in gown: About accessible (criminal) legal language]. Deventer: Kluwer.

Reinsma, M., \& Reinsma, R. (1976). 'De vrouw wier lichaam zich eerstbedoeld leven ontwikkelt', of Zestig jaar Nederlandse rechtstaal ["The woman whose body develops first-mentioned life", or Sixty years of Dutch legal language]. Nederlands Juristenblad, 51(26), 857-872.

Sanders, T., \& Jansen, C. (2011). Begrijpelijke taal. Fundamenten en toepassingen van effectieve communicatie [Understandable language. Fundamentals and applications of effective communication]. Tijdschrift voor taalbeheersing, 33(3), 201-207.

Van der Bruggen, G. (2018). In de beperking toont zich de meester. Negen kenmerken van uitspraken in klare taal [The master shows himself in the limitation. Nine characteristics of judgments in clear language]. Nederlands Tijdschrift voor Bestuursrecht, 72(10), 463-467. 
Geerlings, M., \& Montfort, A. V. (2020). What exactly did the judge decide? Clear language and well-arranged structure lead to better comprehensible court judgments. Archives of Business Research, 8(1), 248-260.

Van der Pool, E., \& Van Wijk, C. (2010). Burgers over de begrijpelijkheid van rechtbankbrieven [Citizens about the comprehensibility of court letters]. Trema, tijdschrift voor de Rechterlijke Macht, 33(6), 244-248.

Verkuylen, M. W. (2002). Begrijpelijkheid van strafrechtelijke vonnissen [Comprehensibility of criminal law judgments] (Master's thesis). Amsterdam: Vrije Universiteit. 